\title{
HUBUNGAN TINGKAT PENGETAHUAN DAN LINGKUNGAN SOSIAL DENGAN PERILAKU MEROKOK
}

\author{
Dinar Ariasti, Endang Dwi Ningsih \\ AKPER PANTI KOSALA SURAKARTA, Sukoharjo, Jawa Tengah, Indonesia
}

\begin{abstract}
Abstrak
Latar Belakang. Merokok dapat menyebabkan gangguan kesehatan. Riskesdas tahun 2018 menunjukkan bahwa prevalensi merokok pada remaja usia 10-18 tahun mengalami peningkatan dari tahun $2013(7,20 \%)$ ke tahun 2018 (9,10\%) sehingga masih sangat jauh dari target RPJMN 2019 yaitu sebesar 5,4\%.

Tujuan Penelitian. Mengetahui hubungan tingkat pengetahuan dan faktor lingkungan sosial dengan perilaku merokok.

Subyek dan Metode. Penelitian ini merupakan analitik observasional dengan desain korelasional. Subyek penelitian siswa laki-laki yang merokok di SMA Negeri 8, sampel diambil berdasarkan tabel Kretjie, data dianalisa dengan uji Korelasi Spearman Rank.

Hasil Penelitian. Terdapat hubungan tingkat pengetahuan $(p=0,001 ; r=-0,591)$ dan lingkungan keluarga $(p=0,028 ; r=0,272)$ tetapi tidak terdapat hubungan lingkungan sekolah $(p=0,105)$ dan lingkungan masyarakat $(p=0,056)$ dengan perilaku merokok.

Kesimpulan. Terdapat hubungan tingkat pengetahuan dan lingkungan keluarga dengan perilaku merokok tetapi tidak terdapat hubungan lingkungan sekolah dan lingkungan masyarakat dengan perilaku merokok.
\end{abstract}

Kata kunci: lingkungan sosial, pengetahuan, perilaku merokok

\section{THE RELATIONSHIP OF LEVEL KNOWLEDGE AND SOCIAL ENVIRONMENT WITH SMOKING BEHAVIOR}

\begin{abstract}
Background. Smoking can cause health problems. Riskesdas in 2018 showed that the prevalence of smoking in adolescents aged 10-18 years has increased from 2013 (7.20\%) to $2018(9.10 \%)$ so that it is still very far from the RPJMN of 2019 was $5.4 \%$. The Aim of the Study. To determine the relationship of the level of knowledge and social environmental factors with smoking behavior of students of SMA Negeri 8 Surakarta.

Subjects and Methods. This research is an observational analytic with correlational design. Subjects were male students who smoked in SMA Negeri 8, samples were taken based on the Kretjie table, data were analyzed with the Spearman Rank Correlation test.

Results. There is a relationship between the level of knowledge $(p=0.001 ; r=-0.591)$ and the family environment $(p=0.028 ; r=0.272)$ but there is no relationship between the school environment $(p=0.105)$ and the community environment $(p=0.056)$ with smoking behavior.

Conclusion. There is a relationship between the level of knowledge and family environment with smoking behavior but there is no relationship between the school environment and the community environment with smoking behavior.
\end{abstract}

Keywords: knowledge, smoking behavior, social environment.

Korespondensi: Dinar Ariasti. AKPER PANTI KOSALA SURAKARTA, Jalan Raya SoloBaki Km. 4 Gedangan, Grogol, Sukoharjo, Jawa Tengah. Email: ariasti98@gmail.com 


\section{LATAR BELAKANG}

Merokok telah menjadi kebiasaan sebagian besar orang. Bahkan sudah banyak yang mengalami gangguan kesehatan akibat merokok. Namun kenyataan menunjukkan bahwa masih banyak orang yang belum mengetahui secara jelas mengenai akibat asap rokok terhadap kesehatan.

Menurut Riset Nasional Dasar Kesehatan tahun 2013, prevalensi merokok di Indonesia yang berusia 15 tahun ke atas meningkat dari $34,2 \%$ di 2007 menjadi $34,7 \%$ pada tahun 2010, dan menjadi $36,3 \%$ pada tahun 2013. Persentase memulai menggunakan tembakau dalam setiap kelompok usia adalah: 5-9 tahun - 0,7\%, 10-14 tahun 9,5\%, $15-19$ tahun $50,3 \%, 20-24$ tahun $26,7 \%, 25-29$ tahun $7,6 \%,>30$ tahun 5,2\%. Riskesdas tahun 2018 menunjukkan bahwa prevalensi merokok pada remaja usia 10-18 tahun mengalami peningkatan dari tahun $2013(7,20 \%)$ ke tahun 2018 $(9,10 \%)$. Angka tersebut masih sangat jauh dari target RPJMN 2019 yaitu sebesar $5,4 \%$. Sedangkan perokok laki-laki usia $>15$ tahun pada tahun 2018 masih berada pada angka yang tinggi $(62,9 \%)$ dan masih menjadi prevalensi perokok laki-laki tertinggi di dunia.

Menurut Sholeh (2017), ada banyak faktor yang menjadi penyebab orang merokok, sehingga perlu pemahaman untuk mengantisipasi akibat yang ditimbulkan. Faktor yang menyebabkan anak merokok antara lain contoh dari orang tua, guru, keluarga, lingkungan pergaulan, akses yang mudah untuk mendapatkan rokok, banyaknya iklan rokok di kalangan remaja, merasa lebih percaya diri dan bisa konsentrasi dengan merokok.

Lingkungan tempat sosialisasi anak akan mempengaruhi pembentukan karakter dan kebiasaan anak. Disamping lingkungan keluarga yang harus bebas dari kebiasaan buruk merokok, juga lingkungan pendidikan dan lingkungan pertemanan. Yang terpenting adalah bagaimana menjaga agar lingkungan sosial dan juga pergaulan dari anak tidak berpengaruh buruk terhadap perilaku remaja tersebut, salah satunya adalah perilaku merokok (Sholeh, 2017).

Hasil penelitian Febrianika, Widijanarko dan Kusumawati (2016), yang berjudul hubungan faktor lingkungan sosial dengan perilaku merokok siswa laki-laki di SMA $X$ kabupaten Kudus menunjukkan sebagian besar responden mendapat dukungan merokok dari lingkungan keluarga $(82,8 \%)$, teman sebaya $(57 \%)$, sekolah (51,6\%), masyarakat $(78,5 \%)$ dengan hasil uji statistik yang berhubungan yaitu dukungan keluarga $(p=0,034)$, dukungan teman $\quad(p=0,023)$, dukungan masyarakat $(p=0,020)$ dan yang tidak berhubungan yaitu dukungan sekolah $(p=0,269)$.

Pengetahuan merupakan hasil dari tahu, dan ini terjadi setelah seseorang melakukan pengindraan terhadap suatu obyek tertentu. Pengindraan terjadi melalui panca indera manusia yaitu indra penglihatan, penciuman, pendengaran, rasa dan raba. Pengetahuan dan kognitif merupakan domain yang sangat penting dalam membentuk tindakan seseorang (Fitriani, 2011). Menurut Wawan dan Dewi (2010) pengetahuan atau kognitif merupakan domain yang sangat penting untuk terbentuknya tindakan seseorang (overt behavior).

Perilaku adalah respon individu terhadap suatu stimulus atau suatu tindakan yang dapat diamati dan mempunyai frekuensi spesifik, durasi dan tujuan baik disadari maupun tidak. Perilaku merupakan kumpulan berbagai faktor yang 
saling berinteraksi. Dengan demikian disimpulkan bahwa perilaku itu dibentuk melalui suatu proses dan berlangsung dalam interaksi manusia dengan lingkungannya. Faktor yang mempengaruhi terbentuknya perilaku dibedakan menjadi 2 yaitu faktor intern dan ekstern. Faktor intern mencakup pengetahuan, kecerdasan, persepsi, emosi, motivasi, yang berfungsi untuk rangsangan dari luar. Sedangkan faktor ekstern meliputi lingkungan sekitar, baik fisik maupun non fisik seperti iklim, manusia, sosial ekonomi, kebudayaan (Wawan dan Dewi, 2010).

Perilaku yang dihadapi remaja di sekolah dapat dikatakan masih dalam kategori wajar jika tidak merugikan dirinya sendiri dan orang lain. Perilaku remaja yang bermasalah salah satunya adalah merokok dapat menghambat remaja untuk bersosialisasi dengan remaja yang lain, guru, dan masyarakat. Perilaku menyimpang pada remaja merupakan perilaku yang kacau yang menyebabkan remaja menjadi gugup dan tidak terkontrol. Perilaku menyimpang dapat berdampak negatif bagi remaja yaitu tindakan yang tidak terkontrol dan akan mengakibatkan pada sebuah kejahatan.

Hasil penelitian Hasriani, Sewang, dan Muzakkir (2014), yang berjudul hubungan pengetahuan dengan perilaku merokok siswa kelas 11 SMP Negeri 30 Makasar menunjukan bahwa hasil analisa statistik menunjukkan nilai $p=0,000$ $\leq \alpha(0,05)$ maka dapat diartikan ada hubungan yang signifikan antara pengetahuan dengan perilaku merokok.

Hasil penelitian yang dilakukan Maseda, Suba, dan Wongkar (2013), tentang hubungan pengetahuan dan sikap terhadap bahaya merokok dengan perilaku merokok pada remaja putra di SMA
Negeri I Tompasobaru, nilai probabilitas hubungan pengetahuan tentang bahaya merokok dengan perilaku merokok sebesar 0,015 sedangkan hubungan sikap tentang bahaya merokok dengan perilaku merokok sebesar 0,000 yang berarti ada hubungan antara pengetahuan dan sikap tentang bahaya merokok dengan perilaku merokok pada remaja putra di SMA Negeri I Tompasobaru. Penelitian yang dilakukan Sutha (2016), tentang analisis kondisi lingkungan sosial terhadap perilaku merokok remaja di Kecamatan Pangarengan Kabupaten Sampang diketahui ada hubungan antara anggota keluarga/orangtua dengan perilaku merokok, nilai $x^{2}=0,000<\alpha=(0,05)$. Dari beberapa penelitian di atas terdapat beberapa faktor yang mempengaruhi perilaku merokok yaitu pengetahuan, sikap dan anggota keluarga yang merokok.

Hasil studi pendahuluan di SMA Negeri 8 Surakarta dengan melakukan wawancara langsung dengan 5 siswa laki-laki. Mereka mengatakan menghisap rokok dengan alasan mengikuti teman dan tidak mengetahui dampak dari merokok bagi kesehatan, sehingga siswa laki laki menganggap bahwa merokok itu hal yang biasa.

Perbedaan penelitian ini dengan penelitian sebelumnya adalah variabel yang diambil dan lokasi penelitian.

\section{TUJUAN PENELITIAN}

Mengetahui hubungan tingkat pengetahuan dan faktor lingkungan sosial dengan perilaku merokok siswa laki-laki di SMA Negeri 8 Surakarta.

\section{METODE}

Penelitian ini adalah penelitian observasional analitik dengan desain korelasi menggunakan pendekatan cross sectional. Alat ukur yang digunakan kuesioner. 
Data dianalisa menggunakan uji Korelasi Spearman Rank (Rho).

\section{SUBJEK}

Penelitian dilakukan di SMA Negeri 8 Surakarta dengan populasi siswa laki-laki yang merokok dan sampel siswa kelas XI dan XII sebanyak 65 responden yang diambil dengan tabel Kretjie.

\section{HASIL}

Karakteristik responden dalam penelitian ini meliputi kelompok umur, sedangkan analisis univariat meliputi tingkat pengetahuan dan lingkungan sosial serta perilaku merokok, yaitu sebagai berikut:

Tabel 1.

Karakteristik Responden

\begin{tabular}{|c|c|c|}
\hline $\begin{array}{c}\text { Kelompok } \\
\text { Umur }\end{array}$ & $\mathrm{n}$ & $\%$ \\
\hline 16 & 20 & 30,8 \\
\hline 17 & 29 & 44,6 \\
\hline 18 & 16 & 24,6 \\
\hline Jumlah & 65 & 100 \\
\hline
\end{tabular}

Tabel 1 di atas menunjukkan umur responden berkisar antara 16 sampai 18 tahun dengan umur terbanyak adalah 17 tahun yaitu 29 responden $(44,6 \%)$, dan paling sedikit umur 18 tahun yaitu 16 responden $(24,6 \%)$.
Hasil analisis univariat dalam penelitian ini yaitu :

Tabel 2.

Distribusi Frekuensi Tingkat

Pengetahuan dan Lingkungan Sosial dengan Perilaku Merokok

\begin{tabular}{lcc}
\hline \multicolumn{1}{c}{ Variabel } & $\mathrm{n}$ & $\%$ \\
\hline Tingkat Pengetahuan & 12 & 18,5 \\
$\begin{array}{l}\text { Rendah } \\
\text { Tinggi }\end{array}$ & 53 & 81,5 \\
Lingkungan keluarga & & \\
Merokok & 49 & 75,4 \\
Tidak Merokok & 16 & 24,6 \\
Lingkungan sekolah & & \\
Merokok & 55 & 84,6 \\
Tidak Merokok & 10 & 15,4 \\
Lingkungan Masyarakat & & \\
Merokok & 52 & 80,0 \\
Tidak Merokok & 13 & 20,0 \\
Perilaku Merokok & & \\
Ringan & 53 & 81,5 \\
Sedang & 12 & 18,5 \\
\hline
\end{tabular}

Dari Tabel 2 diketahui ada 53 responden $(81,5 \%)$ mempunyai tingkat pengetahuan tinggi, 12 responden $(18,5 \%) \quad$ mempunyai tingkat pengetahuan sedang dan tidak ada responden dengan tingkat pengetahuan rendah.

Ditemukan sebagian besar responden sejumlah 49 orang $(75,4 \%)$ dengan lingkungan keluarga merokok, 55 orang $(84,6 \%)$ lingkungan sekolah merokok dan 52 (80\%) lingkungan masyarakat sekitar rumah merokok. Paling banyak 53 responden $(81,5 \%)$ mempunyai perilaku merokok ringan dan 12 responden (18,5\%) perilaku merokoknya sedang. 
Tabel 3.

Tabulasi Silang Hubungan Tingkat Pengetahuan dan Lingkungan Sosial dengan Perilaku Merokok

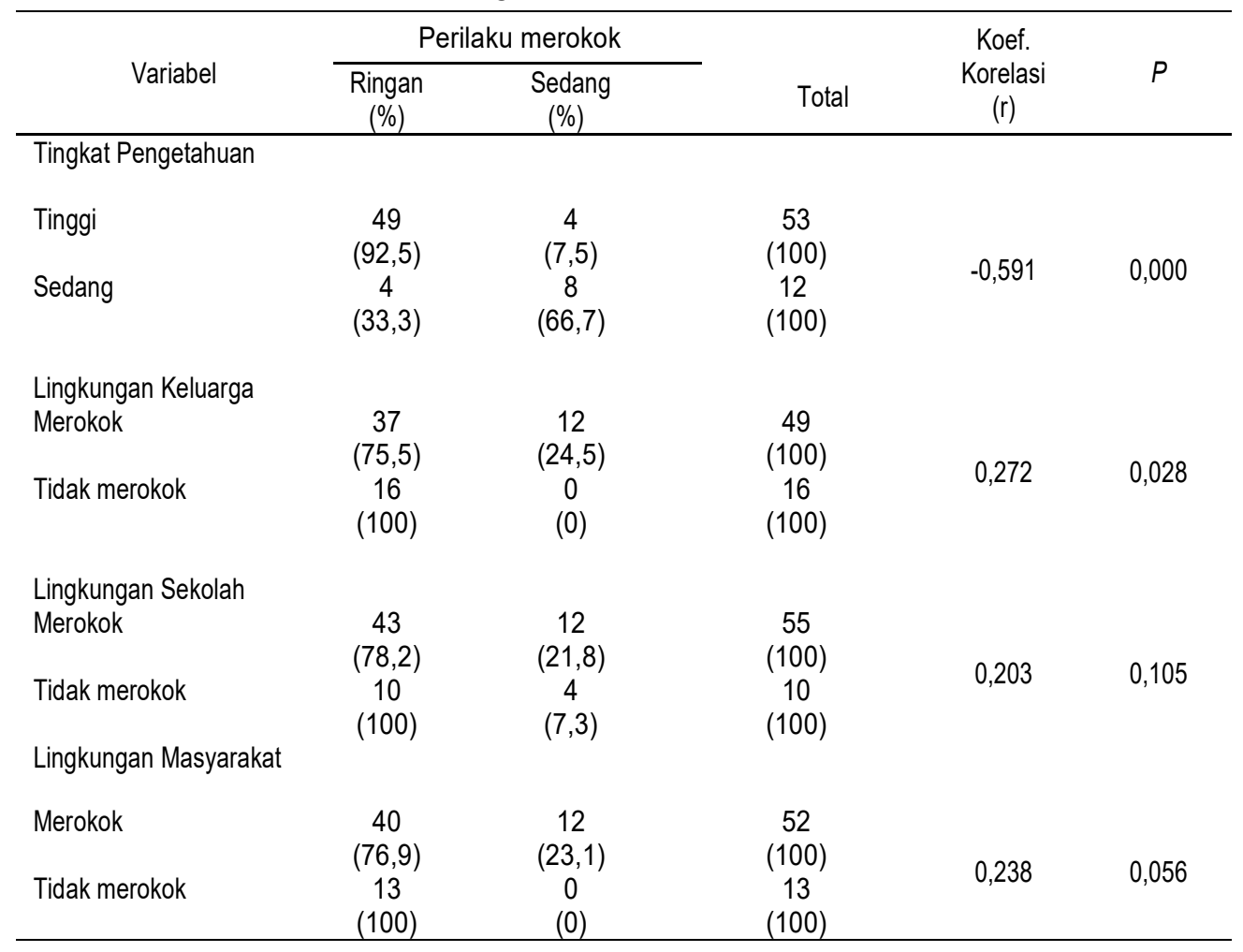

Dari koefisien korelasi untuk tingkat pengetahuan didapatkan sebesar 0,591 artinya kekuatan korelasi sedang dan menunjukkan korelasi negatif yang berarti bahwa semakin tinggi pengetahuan semakin rendah perilaku merokok. Sedangkan untuk lingkungan keluarga didapatkan koefisien korelasi 0,272 artinya kekuatan korelasi lemah dan menunjukkan korelasi positif yang berarti bahwa lingkungan keluarga yang merokok menaikkan perilaku merokok.

Sedangkan hasil analisa bivariat untuk lingkungan sekolah $(p=0,105)$ dan lingkungan masyarakat $(p=0,056)$ menunjukkan bahwa $p-$ value > 0,05 yang berarti tidak terdapat hubungan antara lingkungan sekolah dan lingkungan masyarakat dengan perilaku merokok.
Tabel 4

Hasil Analisis Multivariat

\begin{tabular}{lcccc}
\multicolumn{5}{c}{ Hasil Analisis Multivariat } \\
\hline Variabel & $p$ & $B$ & OR & $\begin{array}{l}\text { Nagelkerke } R \\
\text { Square }\end{array}$ \\
& & & & \\
\hline Pengetahuan & 0,000 & 3,401 & 30,000 & \\
Keluarga & 0,999 & $-17,742$ &, 000 & 0,561 \\
Sekolah & 0,999 & $-20,090$ &, 000 & \\
Masyarakat & 1,000 & $-2,311$ &, 099 & \\
\hline
\end{tabular}

Pada Tabel 4 di atas menunjukkan bahwa variabel yang paling dominan terhadap perilaku merokok adalah tingkat pengetahuan dengan $p$-value 0,000 , dan didapatkan nilai Nagelkerke $R$ Square sebesar 0,561 artinya bahwa variabel perilaku merokok $56,1 \%$ dipengaruhi oleh variabel tingkat pengetahuan sedangkan 43,9\% dipengaruhi oleh faktor lain yang tidak terdapat dalam variabel penelitian ini. Sedangkan untuk variabel yang lain menunjukkan tidak ada pengaruh pada perilaku merokok. 


\section{PEMBAHASAN}

Berdasarkan hasil analisa univariat di atas ditemukan ada 53 responden $(81,5 \%)$ atau sebagian besar responden mempunyai tingkat pengetahuan tinggi, 12 responden $(18,5 \%) \quad$ mempunyai tingkat pengetahuan rendah. Responden sebagian besar memiliki tingkat pengetahuan tinggi karena sudah banyak sosialisasi tentang dampak merokok dan bahaya merokok yang diperoleh baik dari penyuluhan kesehatan, bimbingan konseling guru, media sosial, serta posterposter tentang bahaya merokok yang ditempel di majalah dinding sekolah. Hal ini seperti yang dikemukakan oleh Induniasih dan Ratna (2017), pengetahuan adalah hasil yang didapat setelah orang melakukan penginderaan terhadap objek tertentu. Sebagian besar pengetahuan diperoleh melalui mata dan telinga. Pengetahuan merupakan pedoman dalam membentuk tindakan seseorang. Responden sedang menjalani pendidikan sekolah menengah atas dimana para siswa akan dibekali pendidikan tentang kesehatan melalui pembelajaran yang diberikan. Seperti yang dikemukakan oleh Notoatmodjo (2014), bahwa pengetahuan dipengaruhi oleh faktor pendidikan formal dan sangat erat hubungannya. Diharapkan dengan pendidikan yang tinggi maka akan semakin luas pengetahuannya. Semakin banyak aspek positif dan objek yang diketahui, maka akan menimbulkan sikap semakin positif terhadap objek tertentu. Seperti yang dibuktikan oleh penelitian yang dilakukan oleh Dharmawati dan Wirata (2016), dengan hasil penelitian terdapat hubungan antara tingkat pendidikan dengan tingkat pengetahuan kesehatan gigi dengan nilai signifikasi $(0,037<0,05)$. Adanya hubungan antara pendidikan dengan tingkat pengetahuan karena tidak dapat dipungkiri bahwa makin tinggi tingkat pendidikan seseorang semakin tinggi pula mereka menerima informasi dan pada akhirnya makin banyak pula pengetahuan yang dimiliki. Peningkatan pengetahuan tidak mutlak diperoleh dari pendidikan formal saja, tetapi juga dapat diperoleh dari pendidikan non formal. Seperti yang diungkapkan Long dalam Nursalam dan Pariani (2010), informasi merupakan fungsi penting untuk membantu mengurangi rasa cemas. Seseorang yang mendapat informasi akan mempertinggi tingkat pengetahuan terhadap suatu hal. Responden juga banyak mendapatkan informasi tentang merokok dari media yang lain selain pendidikan formal seperti dari media elektroknik dan media sosial. Hal ini diperkuat oleh penelitian yang dilakukan Hakim dan Kadarullah (2016), dengan hasil penelitian menggunakan uji Korelasi Spearman Rank (Rho) menunjukkan koefisien korelasi sebesar 0,492 dengan nilai signifikasi $0,00<0,05$. Hal ini menunjukkan bahwa ada hubungan banyaknya media massa dengan tingkat pengetahuan kesehatan reproduksi pada remaja di SMAN 1 Purwokerto.

Hasil penelitian hubungan tingkat pengetahuan dengan perilaku merokok didapatkan hasil angka koefisen korelasi $(r)=-0,591$ yang berarti tingkat korelasi sedang antara variabel tingkat pengetahuan dengan perilaku merokok. Hasil nilai signifikansi untuk penelitian ini adalah $0,000(\alpha<0,05)$ yang dapat diartikan ada hubungan yang signifikan antara tingkat pengetahuan dengan perilaku merokok pada siswa laki-laki di SMA Negeri 8 Surakarta. Menurut Rogers yang dikutip oleh Wawan dan Dewi (2010), perilaku adalah semua kegiatan atau aktifitas manusia baik yang dapat diamati langsung 
maupun tidak dapat diamati oleh pihak luar. Sedangkan sebelum mengadopsi perilaku baru di dalam diri orang tersebut terjadi proses yang berurutan, yakni menyadari dalam arti mengetahui terlebih dahulu terhadap stimulus (objek). Dengan adanya pengetahuan responden dapat mempertimbangkan baik buruknya perilaku atau tindakan yang akan dilakukan. Hal ini diperkuat dengan penelitian yang dilakukan Rahayu (2017) dengan hasil penelitian menunjukkan Chi Kuadrat hitung = 4,057 dengan $p=0,044$. Oleh karena hasil perhitungan menunjukkan bahwa $p<0,05$ maka dapat diartikan terdapat hubungan yang signifikan antara tingkat pengetahuan bahaya merokok dengan perilaku merokok pada mahasiswa di Universitas Muhammadiyah Surakarta. Didukung pula oleh penelitian Andika, Khairsyaf dan Pertiwi (2016) yang mendapatkan hasil setengah responden berpengetahuan baik $(60 \%)$, sedangkan sisanya berpengetahuan cukup (21\%) dan berpengetahuan buruk (19\%). Secara statistik terdapat hubungan yang bermakna antara tingkat pengetahuan dengan kejadian merokok $(p=0,000)$. Pengetahuan dan kognitif merupakan domain yang sangat penting dalam membentuk tindakan seseorang (Fitriani, 2011). Menurut Induniasih dan Ratna (2016), perilaku tidak selalu mengikuti dan didasari dengan pengetahuan dan sikap positif. Begitu pula sebaliknya. Akan tetapi, perilaku yang positif yang didasari oleh pengetahuan yang memadai tentang perilaku kesehatan akan membuat seseorang berperilaku sehat lebih langgeng atau awet.

Hasil analisis multivariat didapatkan hasil variabel yang paling dominan terhadap perilaku merokok adalah tingkat pengetahuan dengan $p$-value
0,000 dan didapatkan nilai Nagelkerke $R$ Square sebesar 0,561 artinya bahwa variabel perilaku merokok $56,1 \%$ dipengaruhi oleh variabel tingkat pengetahuan. Hasil nilai $\mathrm{OR}=30,000$ untuk pengetahuan menunjukkan hasil analisis ini sah untuk diinterpretasikan dalam analisis pengaruh bersama-sama (multivariat) karena nilai $\mathrm{OR}>2$. Dari hasil analisa tersebut menunjukkan bahwa pengetahuan kuat dalam merubah atau membentuk perilaku seseorang dibandingkan faktor yang lain. Hal ini diperkuat oleh penelitian yang dilakukan Rochayati dan Hidayat (2015), dengan hasil faktor yang paling dominan mempengaruhi kebiasaan merokok pada remaja SMK adalah pengetahuan remaja tentang rokok dengan nilai $\mathrm{RO}=$ 8,842. Menurut Induniasih dan Ratna (2016), pemberian informasiinformasi tentang cara mencapai hidup sehat, cara memelihara kesehatan, cara menghindari penyakit, dan sebagainya akan membuat pengetahuan tentang halhal yang berkaitan dengan kesehatan akan meningkat. Pengetahuan-pengetahuan tersebut sedikit demi sedikit akan dapat menggugah kesadaran tentang pentingnya berperilaku sehat sesuai dengan pengetahuan kesehatan yang telah diberikan.

Pada tabel 2 ditemukan sejumlah 49 orang $(75,4 \%)$ dengan lingkungan keluarga merokok, 55 orang $(84,6 \%)$ lingkungan teman sekolah merokok dan $52 \quad(80 \%)$ lingkungan tetangganya merokok. Dapat disimpulkan sebagian besar siswa yang merokok lingkungan sosialnya juga perokok. Menurut pendapat Sartain dalam Hasbullah (2015), lingkungan pengaruhnya sangat besar terhadap anak sebab sebagaimanapun anak tinggal dalam suatu lingkungan yang disadari atau tidak pasti akan 
mempengaruhi anak. Pendapat ini menunjukkan bahwa tingkah laku, pertumbuhan dan perkembangan seseorang dapat dipengaruhi oleh kondisi dan alam yang ditinggali oleh seseorang, karena seseorang yang tinggal di suatu lingkungan dengan waktu yang lama menyebabkan tingkah laku seseorang berubah sesuai dengan lingkungan tersebut. Hasbullah (2015), juga menyebutkan bahwa terdapat tiga lingkungan yang mempengaruhi tumbuh kembang dan perilaku anak yaitu lingkungan keluarga, sekolah dan masyarakat. Seperti halnya penelitian yang dilakukan Windahsari, Candrawati dan Warsono (2017), membuktikan bahwa sebagian besar $17(68,0 \%)$ responden remaja di Desa $T$ Mojokerto berada pada faktor lingkungan merokok dan sebagian besar $18 \quad(72,0 \%)$ responden memiliki perilaku merokok kategori sedang dengan uji Spearman rho didapatkan nilai $p$ value $=0,005<\alpha$ $(0,05)$ yang berarti $\mathrm{HO}$ ditolak, artinya ada hubungan faktor lingkungan dengan perilaku merokok pada remaja laki-laki di Desa $T$ kabupaten Mojokerto, dimana semakin negatif lingkungan akan menyebabkan semakin tinggi pula perilaku merokok pada remaja.

Dari analisa bivariat didapatkan hasil hanya faktor lingkungan keluarga yang memiliki hubungan yang signifikan dengan perilaku merokok walapun nilai koefisien korelasinya lemah dengan nilai $(p=0,028, r=0,272)$. Sesuai dengan yang diungkapkan oleh (King, 2013), bahwa keluarga merupakan lingkungan yang sangat berpengaruh bagi perkembangan anak yang bertanggung jawab terhadap penanaman nilai dan norma dalam pembentukan perilaku anak. Orang tua menjadi panutan bagi anak-anaknya baik perilaku positif maupun negatif. Pola asuh yang salah dari orang tua dapat menyebabkan anaknya terjerumus ke dalam perbuatan yang menyimpang seperti merokok, memakai obat-obatan terlarang, pergaulan bebas. Hal ini sesuai dengan penelitian yang dilakukan Riadinata (2018) dengan hasil penelitian $p$-value $=0,009(p<$ $0,05)$, yang artinya terdapat hubungan antara lingkungan keluarga dengan perilaku merokok pada remaja di desa Gonilan Kartasura. Sejalan juga dengan penelitian yang dilakukan oleh Kustanti (2014) yang menunjukkan uji hipotesisnya dengan hasil $p$ value 0,003 yang artinya terdapat hubungan antara lingkungan keluarga dengan perilaku merokok remaja di SMPN I Slogohimo Wonogiri. Begitu pula penelitian yang dilakukan Sulistyawan (2012) dengan hasil ada hubungan orangtua yang merokok $(p=0,000)$ dan saudara serumah yang merokok $(p=0,001)$ dengan perilaku merokok siswa SMP Negeri 3 Tangerang Selatan.

Secara bivariat variabel lingkungan sekolah dan masyarakat menunjukkan tidak terdapat hubungan yang signifikan dengan perilaku merokok dengan nilai $(p=0,105, r=0,203)$ untuk lingkungan sekolah dan $(p=0,056, \quad r=0,238)$ untuk lingkungan masyarakat. Hal ini didukung oleh penelitian terdahulu yang dilakukan oleh Febrianika, Widjanarko dan Kusumawati (2016) dengan hasil penelitian tidak ada hubungan antara lingkungan sekolah dengan perilaku merokok $(p=0,269)$. Didukung pula oleh penelitian yang dilakukan oleh Widianti dan Wahyono (2014), dengan hasil uji Chi kuadrat diperoleh nilai $p=0,083$ $(p>0,05)$ yang berarti tidak ada hubungan yang signifikan antara perilaku guru dengan perilaku merokok di salah satu SMP Negeri di Kota Bogor. Hal ini dimungkinkan karena adanya peraturan yang ketat 
dilingkungan sekolah tentang larangan merokok di lingkungan sekolah. Berdasarkan hasil penelitian, lingkungan masyarakat juga kurang berpengaruh membentuk perilaku merokok siswa SMA Negeri 8 Surakarta. Meskipun semua orang tahu akan bahaya yang ditimbulkan akibat merokok, perilaku merokok masih merupakan perilaku yang dapat ditoleransi oleh masyarakat dan dianggap hal yang wajar oleh masyarakat disekitar. Hal ini didukung oleh penelitian yang dilakukan Fikriyah dan Febrijanto (2012), setelah dilakukan uji statistik Regresi Linier Ganda yang didasarkan taraf kemaknaan yang ditetapkan $(\alpha \leq 0,05)$ didapatkan $p=$ 0,760 maka $\mathrm{Ho}$ diterima dan $\mathrm{Ha}$ ditolak yang artinya tidak ada pengaruh faktor lingkungan terhadap perilaku merokok pada mahasiswa laki-laki di asrama putra STIKES RS Baptis Kediri. Berbeda dengan penelitian yang dilakukan oleh Riyandi, Wiyono dan Candrawati (2017) dengan hasil penelitian terdapat hubungan lingkungan sosial dengan perilaku merokok pada wanita di Kota Malang dengan hasil $p$-value $=0,003$ $<\alpha(0,05)$. Begitu juga penelitian yang dilakukan oleh Setiana dan Tahlil (2016) dengan hasil ada hubungan lingkungan sosial dengan perilaku merokok remaja $(p=$ $0,001)$, dan ada hubungan lingkungan kultural dengan perilaku merokok remaja $(p=0,006)$.

\section{KESIMPULAN}

Hasil analisa bivariat untuk tingkat pengetahuan $\quad(p=0,001) \quad$ dan lingkungan keluarga $(p=0,028)$ menunjukkan bahwa $p$-value $<0,05$ yang berarti bahwa ada hubungan antara tingkat pengetahuan tentang merokok dan lingkungan keluarga dengan perilaku merokok dan tidak terdapat hubungan antara lingkungan sekolah $(p=0,105)$ dan lingkungan masyarakat dengan perilaku merokok $(p=0,056)$. Sedangkan saat dianalisa bersamasama variabel yang paling dominan terhadap perilaku merokok adalah tingkat pengetahuan dengan $p$-value 0,000 dan didapatkan nilai Nagelkerke $R$ Square sebesar 0,561 artinya bahwa variabel perilaku merokok $56,1 \%$ dipengaruhi oleh variabel tingkat pengetahuan.

\section{SARAN}

Perilaku merokok merupakan perilaku yang memberikan banyak dampak negatif pada remaja untuk itu diharapkan pihak sekolah dapat mengadakan edukasi berkala kepada siswa dan orangtua tentang rokok dan bahayanya untuk mencegah perilaku merokok pada siswa. Keluarga dapat memberikan perhatian dan peraturan yang tegas untuk anak serta menjadi role model yang baik untuk mencegah perilaku merokok.

Peneliti selanjutnya dapat melakukan penelitian yang berkaitan dengan perilaku merokok menggunakan cakupan responden yang lebih luas dan faktor-faktor yang lain seperti pendidikan, pola asuh, dukungan keluarga, sikap maupun motivasi.

\section{DAFTAR PUSTAKA}

Andika, D., O. Khairsyah dan D. Pertiwi 2016. Hubungan Pengetahuan dengan Kejadian Merokok pada Pelajar SMPN 1 Pariaman.

http://jurnal.fk.unand.ac.id

Diakses pada tanggal 22 April 2020.

Dharmawati, A. I. G. A. dan Wirata, I. N. 2016. "Hubungan Tingkat Pendidikan, Umur dan Masa Kerja". Jurnal Kesehatan Gigi. Volume 4. Diakses 15 April 2020.

Febrianika, R., B. Widjanarko, dan A. Kusumawati. 2016. Hubungan Faktor Lingkungan Sosial dengan Perilaku Merokok 
Siswa Laki- Laki di SMA $X$ Kabupaten Kudus. https://ejournal3. undip.ac.id. Diakses pada tanggal 10 Desember 2019.

Fikriyah, S dan Y. Febrijanto. 2012. Faktor-Faktor yang Mempengaruhi Perilaku Merokok pada Mahasiswa LakiLaki di Asrama Putra http://puslit2.petra.ac.id/ejournal /index.php/stikes/article.

Diakses tanggal 23 April 2020.

Fitriani, S. 2011. Promosi Kesehatan. Graha IImu, Yogyakarta.

Hakim, A. dan O. Kadarullah. 2016. Pengaruh Informasi Media Massa terhadap Pengetahuan Kesehatan Reproduksi pada Siswa

SMA.

http://jurnalnasional.ump.ac.id/in dex.php/PSYCHOIDEA/article/vi ew. Diakses tanggal 15 April 2020.

Hasbullah. 2015. Dasar-dasar IImu Pendidikan. PT Raja Grafindo Persada, Jakarta

Hasriani, N. Sewang dan H. Muzakkir. 2014. Hubungan Pengetahuan dengan Perilaku Merokok Siswa Kelas II SMP Negeri $\quad 30 \quad$ Makasar. http://ejournal.Stikesnh.ac.id.

Diakses pada tanggal 10 Desember 2019.

Induniasih dan W. Ratna. 2017. Promosi Kesehatan; Pendidikan Kesehatan dalam Keperawatan. Pustaka Baru Press, Yogyakarta.

Kementerian Kesehatan RI. Riset kesehatan dasar (Riskesdas) 2013. Kementerian Kesehatan RI, Jakarta.

2018. Riset

Kesehatan Dasar (Riskesdas) 2018. Kementerian Kesehatan RI, Jakarta.

King, L. A. 2013. Psikologi Umum: Sebuah Pandangan Apresiatif. Salemba Medika, Jakarta.
Kustanti, A. A. 2014. Hubungan Antara Pengaruh Keluarga, Pengaruh Teman dan Pengaruh Iklan terhadap Perilaku Merokok pada Remaja di SMP N 1 Slogohimo, Wonogiri. http:eprints.ums.ac.id. diakses 22 Februari 2020.

Maseda, D. R., B. Suba, dan D. Wongkar. 2013. Hubungan Pengetahuan dan Sikap tentang Bahaya Merokok dengan perilaku Merokok pada Remaja Putra di SMA Negeri 1 Tompasobaru. https://ejournal. Unsrat.ac.id. Diakses tanggal 12 Desember 2019.

Notoatmodjo, S. 2014. IImu Perilaku Kesehatan. Rineka Cipta. Jakarta.

Nursalam dan S. Pariani. 2010. Pendekatan Praktis Metodologi Riset Keperawatan. CV. Agung Seto, Jakarta.

Rahayu, P. 2017. Hubungan antara Pengetahuan Bahaya Merokok dengan Perilaku Merokok pada Mahasiswa di Universitas Muhammadiyah Surakarta. http://eprints.ums.ac.id. Diakses 22 April 2020.

Riadinata, E. 2018. Hubungan Lingkungan Keluarga dan Teman Sebaya dengan Perilaku Merokok pada Remaja Usia 1822 tahun di Desa Gonilan Kartasura.

http://eprints.ums.ac.id. Diakses 22 April 2020.

Riyandi, G., J. Wiyono dan E. Candrawati. 2017. Hubungan lingkungan sosial dengan perilaku merokok pada wanita di Kota Malang. https://publikasi.unitri.ac.id. Diakses tanggal 23 April 2020.

Rochayati, A. S., dan E. Hidayat. 2015. Faktor-faktor yang Mempengaruhi Perilaku Merokok Remaja di Sekolah Menengah Kejurusan Kabupaten Kuningan. http://jks.fikes.unsoed.ac.id/inde 
x.php/jks/article. Diakses tanggal 22 April 2020.

Setiana, A. D., dan T. Tahlil. 2016. Faktor Lingkungan dan Hubungannya dengan Perilaku Merokok Remaja di Aceh Besar. http://www.jim.unsyiah.ac.id. Diakses tanggal 23 April 2020.

Sholeh, A. N. 2017. Panduan Merokok untuk Pelajar, Guru dan Orang Tua. Erlangga, Jakarta.

Sulistyawan, A. 2015. FaktorFaktor yang Berhubungan dengan Perilaku Merokok Siswa.

http://repository.uinjkt.ac.id. Diakses tanggal 22 April 2020.

Sutha, D. W. 2016. Analisis Lingkungan Sosial terhadap Perilaku Merokok Remaja di Kecamatan Pangarengan Kabupaten Sampang. Http://jurnal-yrsdds.ac.id.stikes. Diakses tanggal 30 Desember 2019.
Wawan, A. dan M. Dewi. 2010. Teori \& Pengukuran Pengetahuan, Sikap, dan Perilaku Manusia. Nuha Medika, Yogyakarta.

Widianti, E.V.M. dan T.Y.M. Wahyono. 2014. Faktor-faktor yang Berhubungan dengan Perilaku Merokok Siswa SMP Negeri " $X$ " di Kota Bogor. http://lib.ui.ac.id. Diakses 23 April 2020.

Windahsari, N., E. Candrawati dan Warsono. 2017. Hubungan Faktor Lingkungan dengan Perilaku Merokok pada Remaja Laki-laki di Desa T Kabupaten Mojokerto.

https://publikasi.unitri.ac.id/inde x.php/fikes/article.

Diakses tanggal 22 April 2020. 